Volume 2, No. 2, 2020

ISSN (print) : 2656-6117

ISSN (online) : 2715-0356

Homepage : http://journal.iaimsinjai.ac.id/index.php/asy-syarikah

\title{
PRAKTEK JUAL BELI MAPPAJE PADA MASYARAKAT DI DESA BARUGA RIATTANG DALAM PANDANGAN ISLAM
}

\author{
Reskiani1 $^{1}$ Nurwahida ${ }^{2}$ Sukiman $^{3}$ \\ ${ }^{1}($ UIN) Alauddin Makassar, Gowa \\ ${ }^{2}$ Institut Agama Islam Muhammadiyah Sinjai,Sinjai Utara \\ ${ }_{3}^{3}$ Institut Agama Islam Muhammadiyah Sinjai, Sinjai Utara \\ Korespondensi Penulis, Email: \\ ${ }^{1}$ Reskiani21@gmail.com/082343397449 \\ 2nurwahidarusdin19@gmail.com/082395174403 \\ 3Sukimanpaluymbai@gmail.com/082345666433
}

\begin{abstract}
Abstrak
Jenis penelitian ini adalah penelitian lapangan (field research). Penelitian ini menggunakan pendekatan normatif, yaitu bertolak ukur pada hukum Islam. Adapun sumber data penelitian ini, yaitu terdiri dari data primer dan data sekunder. Data primer adalah data yng diperoleh dari pemerintah Desa Baruga Riattang, warga dan tokoh masyarakat. Data sekunder yaitu data pelengkap berupa buku, jurnal dan pustaka lain yang berkaitan dengan penelitian ini. Metode pengumpulan data yang digunakan adalah riset kepustakaan baik dari buku maupun dari hasil penelitian, dan riset lapangan seperti observasi, wawancara (interview) dan dokumentasi. Setelah semua data yang diperlukan terkumpul, maka data tersebut kemudian dinalisis dan disimpulkan. Berdasarkan hasil penelitian yang telah dilakukan oleh penulis, maka dapat disimpulkan bahwa praktik mappaje' yang dilakukan oleh masyarakat Islam di Desa Baruga Riattang Kecamatan Bulukumpa Kabupaten Bulukumba telah sesuai dengan hukum Islam karena rukun dan syarat dalam akad mappaje' telah terpenuhi dan sesuai dengan syariat Islam, barang yang dijadikan objek jual beli pun sudah jelas kelayakannya untuk dipetik atau dipanen.
\end{abstract}

Kata kunci: Jual beli, Mappaje, Etika Bisnis Islam

\begin{abstract}
This type of research is field research. This study uses a normative approach, which is measured against Islamic law. The data source of this research consists of primary data and secondary data. Primary data is data obtained from the village government of Baruga Riattang, residents and community leaders. Secondary data is complementary data in the form of books, journals and other literature related to this research. The data collection method used is library research both from books and from research results, and field research such as observation, interviews and documentation. After all the necessary data have been collected, the data is then analyzed and concluded. Based on the results of research that has been conducted by the author, it can be concluded that the practice of mappaje 'carried out by the Muslim community in Baruga Riattang Village, Bulukumpa District, Bulukumba Regency is in accordance with Islamic law because the pillars and requirements in the mappaje contract have been fulfilled and are in
\end{abstract}




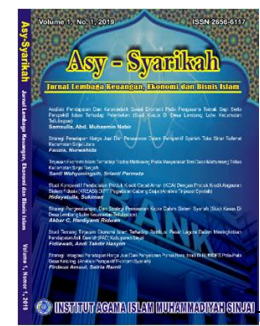

Asy-Syarikah

Jurnal Lembaga Keuangan, Ekonomi dan Bisnis Islam

Volume 2, No. 2, 2020

ISSN (print) : 2656-6117

ISSN (online) : 2715-0356

Homepage : http://journal.iaimsinjai.ac.id/index.php/asy-syarikah

accordance with Islamic law, goods that are used as the object of sale and purchase are clearly eligible to be picked or harvested.

Keywords: Buying and selling, Mappaje, Islamic Business Ethics

\section{Pendahuluan}

Allah swt. memberikan hidayah atau petunjuk kepada manusia agar dapat memenuhi kebutuhan hidupnya, sebab Allah tidak menciptakan seluruh kebutuhan manusia secara permanen atau siap pakai. Namun, Allah memberikan kewenangan kepada manusia untuk memikirkan dan menemukan sendiri apa yang menjadi kebutuhan umat manusia itu sendiri. Hal ini didasarkan pada fitrah yang Allah anugerahkan kepada manusia sebagai mahluk yang sempurna (insan kamil) yang dapat mengelola alam ciptaan Allah ini

Pada dasarnya manusia diciptakan untuk saling berhubungan dan berinteraksi satu sama lain. Dimana, manusia merupakan mahkluk sosial yang saling membutuhkan satu sama lain dalam kehidupannya. Dalam memenuhi kebutuhan hidupnya, manusia senantiasa dituntut untuk berusaha dan bekerja keras untuk memproleh apa yang diinginkan. Posisi manusia dibandingkan ciptaan lainnya bersumber dari fakta bahwa manusia telah ditunjuk sebagai wakil Allah di muka bumi. Penunjukan ini merupakan amanat Allah dalam mengemban tanggung jawab tertentu berdasarkan potensinya agar memerlihatkan bagaimana kemampuan dan kinerja yang diciptakannya. Melalui kecerdasannya, manusia dapat melihat mana yang salah dan mana yang benar, pantas dan tidak pantas.

Eksistensi manusia sebagai makhluk sosial sudah merupakan fitrah yang sudah ditetapkan Allah swt. bagi mereka. Suatu hal yang paling mendasar dalam memenuhi kebutuhan seorang manusia adalah adanya interaksi sosial dengan manusia lain. Dalam kaitan dengan ini, Islam datang dengan dasar-dasar dan prinsip-prinsip yang mengatur secara baik persoalan-persoalan muamalah yang akan dilalui oleh setiap manusia dalam kehidupan sosial mereka. Hubungan antar manusia terikat dengan tata aturan hukum Islam yang dikenal dengan istilah muamalah untuk mengatur hubungan manusia dengan manusia lain dalam hidup dan kehidupan.

Muamalah secara harfiah berarti "pergaulan" atau hubungan antara manusia. Dalam pengartian harfiah yang bersifat umum ini, muamalah berarti perbuatan atau pergaulan manusia di luar ibadah. Muamalah merupakan perbuatan manusia dalam menjalin hubungan atau pergaulan antar sesama manusia, sedangkan ibadah merupakan hubungan atau "pergaulan manusia dengan Tuhan (Ghufran, 2020:1).

Adapun salah satu bentuk muamalah tersebut yaitu jual beli. Kegiatan jual beli berlangsung sejak kehadiran manusia walaupun dalam bentuk yang sederhana. Pada mulanya jual beli hanya berlangsung secara barter, yakni penukaran barang dengan barang, dan perkembangan selanjutnya berlangsung antara penjual dan pembeli dengan penukaran barang dan "sesuatu" yang disimbolkan yang dipandang mengandung nilai (Hamzah Hasan Khaeriyah,, 2013:139). Karena jual beli merupakan kebutuhan dalam kehidupan manusia, artinya manusia tidak dapat hidup tanpa kegiatan jual beli. Landasan syar'i yang menjadi dasar diperbolehkan transaksi jual beli.

Adapun bentuk jual beli yang dilakukan oleh masyarakat di Desa Baruga Riattang adalah mereka menyebutnya dengan istilah mappaje'. Mappaje' merupakan sebuah istilah transaksi dalam hal jual beli yang dilakukan oleh masyarakat di Desa Baruga Riattang Kecamatan Bulukumpa Kabupaten Bulukumba dalam bidang pertanian dan 


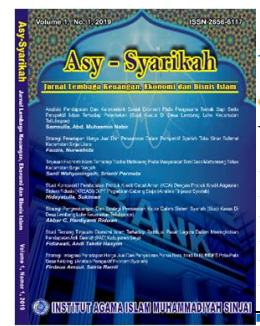

Asy-Syarikah

Jurnal Lembaga Keuangan, Ekonomi dan Bisnis Islam

Volume 2, No. 2, 2020

ISSN (print) : 2656-6117

ISSN (online) : 2715-0356

Homepage : http://journal.iaimsinjai.ac.id/index.php/asy-syarikah

perkebunan, seperti buah-buahan dan biji-bijian. Yang dimaksud dengan mappaje' yaitu suatu proses jual beli hasil tanaman seperti buah-buahan atau biji-bijian yang masih dipohon dalam bentuk penaksiran, dimana buahnya akan diambil atau dipanen oleh si pembeli sesuai dengan kesepakatan di antara kedua belah pihak, penjual dan pemnbeli.

Istilah mappaje' merupakan simbol nama atau bahasa dari masyarakat di Desa Baruga Riattang. Jenis-jenis tanaman yang dijadikan masyarakat Desa Baruga Riattang sebagai obyek barang pada akad mappaje' ini antara lain seperti petai, cengkeh, langsat, durian, dan rambutan.

Masyarakat Desa Baruga Riattang sebagian besar berprofesi sebagai petani. Sehingga dalam memenuhi kebutuhan hidupnya, mereka tidak lepas dari campur tangan pihak lain. Bagi masyarakat yang apabila memiliki kebutuhan yang mendesak dan hasil tanamannya sudah layak dipanen, namun apabila melakukan pemanenan sendiri akan membutuhkan waktu yang cukup lama, maka yang sering terjadi mereka menjualnya kepada orang lain dengan cara mappaje', yakni dengan cara menjual hasil tanamannya yang masih dipohon kepada pembeli mappaje'. Transaksi semacam inilah yang dinamakan praktik mappaje'.

Umat Islam dalam kiprahnya mencari kekayaan dan menjalankan usahanya diharuskan menjadikan Islam sebagai dasarnya dan ridha Allah sebagai tujuan akhir dan utama. Mencari keuntungan dalam melakukan perdagangan merupakan salah satu tujuan, tetapi tidak boleh mengalahkan tujuan utama. Dalam pandangan Islam, jual beli merupakan sarana untuk beribadah kepada Allah. Oleh karena itu, jual beli dan perdagangan tidak boleh lepas dari peran Syari'ah Islamiyah.

Adanya rukun dan syarat dalam jual beli yang harus dipenuhi agar jual beli yang telah dilakukan sah sesuai dengan hukum syara'. Namun, tentunya dalam praktik kehidupan sehari-hari seringkali ditemui adanya beberapa permasalahan yang berkaitan dengan jual beli, terkadang ada beberapa persoalan dimana terdapat kekurangan atau tidak dipenuhinya syarat atau rukun jual beli. Dari sinilah ada beberapa jual beli yang dianggap shahih atau sah dan ada jual beli yang dianggap ghairu shahih atau tidak sah. Dari segi obyek, barang yang diperjualbelikan harus ada, jelas wujud dan sifatnya, jelas jumlah atau takarannya, dapat diserahterimakan, bermanfaat, serta milik sendiri. Sehingga yang terjadi tidak ada salah satu pihak yang merasa dirugikan. Oleh sebab itu, fenomena atau tradisi yang terjadi pada masyarakat di Desa Baruga Riattang sangat menarik untuk diteliti dengan judul 'Perspektif Hukum Islam terhadap Praktik jual beli Mappaje' pada Masyarakat Islam di Desa Baruga Riattang Kecamatan Bulukumpa Kabupaten Bulukumba".

\section{Metode}

\subsection{Jenis dan Lokasi Penelitian}

Jenis penelitian ini adalah penelitian lapangan (field research), yaitu penelitian yang dilakukan langsung terjun ke lapangan guna memperoleh data yang lengkap dan valid mengenai praktik mappaje' di Desa Baruga Riattang Kecamatan Bulukumpa kabupaten Bulukumba.

Lokasi penelitian yang dilakukan untuk memperoleh data berpusat di Desa Baruga Riattang Kecamatan Bulukumpa Kabupaten Bulukumba.

\subsection{Pendekatan penelitian}

Penelitian ini menggunakan pendekatan sosiolosis hukum Islam, yaitu suatu penelitian pendekatan bertolak ukur pada hukum Islam untuk memperoleh kesimpulan bahwa sesuatu itu sesuai atau tidak dengan ketentuan syari'at.

\subsection{Jenis dan Sumber Data}

Adapun jenis data yang disajikan penulis ialah: 


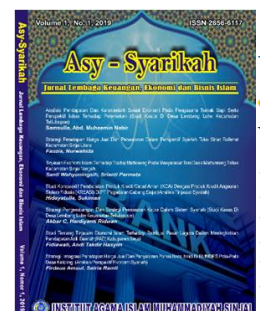

Asy-Syarikah

Jurnal Lembaga Keuangan, Ekonomi dan Bisnis Islam,

Volume 2, No. 2, 2020

ISSN (print) : 2656-6117

ISSN (online) : 2715-0356

Homepage : http://journal.iaimsinjai.ac.id/index.php/asy-syarikah

1. Data kualitatif, adalah data yang digunakan untuk memperoleh gambaran Umum Desa Barugariattang Kecamatan Bulukumpa Kabupaten Bulukumba.

2. Data Kuantitatif, adalah data yang diperoleh berupa angka-angka yang berhubungan dengan penelitian ini.

Adapun sumber data dalam penelitian ini adalah:

1. Data Primer

Data primer adalah sumber data yang dapat memberikan data penelitian secara langsung (Joko P. Subagyo, 1997:88). Adapun sumber data primer dalam penelitian ini adalah pemerintah, warga dan tokoh masyarakat di Desa BarugaRiattang Kecamatan Bulukumpa Kabupaten Bulukumba.

\section{Data Sekunder}

Jenis data sekunder adalah yang dapat dijadikan sebagai pendukung data pokok, atau dapat pula didefinisikan sebagai sumber data yang mampu atau dapat memberikan informasi atau data tambahan yang dapat memperkuat data pokok (Suryadi Suryabrata, , 1998:85). Adapun sumber data yang mendukung dan melengkapi sumber data primer adalah berupa buku, jurnal, majalah dan pustaka lain yang berkaitan dengan tema penelitian.

\subsection{Tekhnik Pengumpulan Data}

Untuk memperoleh informasi dan data sebagai bahan penulisan ini maka penulis menggunakan metode pengumpulan data. Adapun metode pengumpulan data yand dihimpun oleh penulis yaitu:

1. Riset Kepustakaan

Pengumpulan data yang dilakukan dengan cara membaca berbagai buku literatur dan hasil penelitian yang mempunyai relevansi dengan masalah yang akan dibahas dalam skripsi ini.

2. Riset lapangan

Pengumpulan data yang dilakukan secara langsung pada lokasi penelitian, seperti:

a. Observasi

Observasi adalah teknik pengumpulan data yang dilakukan melalui suatu pengamatan, dengan disertai pencatatan-pencatatan terhadap objek sasaran. Dokumentasi

Metode dokumentasi ialah mencari data mengenai hal-hal atau variabel yang berupa catatan, transaksi, buku, surat kabar, majalah, tesis, makalah, dan jenis karya tulis, agenda dan sebagainya (Suharsini Arikunto, 1998:273). Dalam penelitian ini penulis mengambil dokumentasi yang langsung diambil dari obyek penelitian di Desa Baruga Riattang Kecamatan Bulukumpa Kabupaten Bulukumpa.

\subsection{Instrumen Penelitian}

Dalam penelitian field research kualitatif yang menjadi instrumen atau alat penelitian adalahpenelitian sendiri. Penelitian sebagai human instrument berfungsi menetapkan fokus penelitian, yakni mencari informasi dari pemerintah setempat, masyarakat yang melakukan praktik mappaje' dan dari tokoh masyarakat di Desa Baruga Riattang Kecamatan Bulukumpa Kabupaten Bulukumba dengan tujuan untuk mendapatkan gambaran mengenai praktik mappaje' yang terjadi didaerah tersebut. Guna melakukan pengumpulan data, dan membuat kesimpulan atas temuan nantinya (Neong Muhajir, 1998:306), Agar validitas hasil penelitian bisa bergantung pada kualitas instrumen pengumpulan data (Saifuddin Azwar, 2003:94).

Ada beberapa jenis instrumen yang digunakan peneliti yaitu:

1. Panduan observasi, adalah alat bantu yang dipakai sebagai pedoman pengumpulan data pada peroses penelitian. 




Asy-Syarikah

Jurnal Lembaga Keuangan, Ekonomi dan Bisnis Islam

Volume 2, No. 2, 2020

ISSN (print) : 2656-6117

ISSN (online) : 2715-0356

Homepage : http://journal.iaimsinjai.ac.id/index.php/asy-syarikah

2. Pedoman wawancara, adalah alat bantu berupa alat perekam, pulpen, daftar-daftar pertanyaan yang dipakai dalam mengumpulkan data,

3. Data dokumentasi, adalah catatan peristiwa dalam bentuk tulisan langsung atau arsip-arsip, serta foto kegiatan pada saat penelitian.

\subsection{Teknik pengelolaan dan Analisis data}

Pengolahan data merupakan suatu teknik dalam penelitian kualitatif yang dilakukan setelah data lapangan terkumpul. Data terbagi menjadi dua, yaitu data lapangan (data mentah) dan data jadi. Data lapangan atau data mentah merupakan data yang diperoleh saat pengumpulan data. Data mentah pada penelitian ini adalah berupa data lisan (berupa tuturan), data tertulis serta foto. Data lisan dan tertulis tersebut diperoleh melalui wawancara terhadap narasumber atau subjek penelitian. Data yang berupa foto merupakan data yang berfungsi mendeskripsikan suatu hal, benda, maupun kejadian saat observasi maupun saat pengumpulan data.setelah semua data terkumpul yang melalui observasi, wawancara, dan dokumentasi.

\section{Hasil Penelitian Dan Pembahasan}

\subsection{Gambaran Umum Desa Baruga Riattang \\ 3.1.1 Kondisi Geografis}

a. Letak dan Batas Desa Barugariattang

Desa Barugariattang merupakan salah satu desa yang ada dikecamatan bulukumpa kabupaten Bulukumba.Sebagai Desa yang terletak di Kecamatan Bulukumpa, Desa Baruga riattang mempunyai batas wlayah yaitu (Monografi Desa, 2015).

1) Sebelah Utara : Desa Kambuno

2) Sebelah Timur: Desa Keluran Tanete

3) Sebelah Selatan : Desa Balang Taroang

4) Sebelah Barat : Desa Kambuno.

Wilayah Desa Barugariattang Kecamatan Bulukumpa Kabupaten Bulukumba

b. Luas Wilayah

Desa Baruga Riattang mempunyai luas wilayah desa $241 \mathrm{ha} / \mathrm{m}^{2}$

a) Luas Lahan Sawah $: 5,00 \mathrm{ha} / \mathrm{m}^{2}$

b) Luas lahan pemukiman $\quad: 7,00 \mathrm{ha} / \mathrm{m}^{2}$

c) Luas Lahan perkebunan : $: 30,00 \mathrm{ha} / \mathrm{m}^{2}$

d) Luas Pekarangan : $2,00 \mathrm{ha} / \mathrm{m}^{2}$

c. Struktur Organisasi Pemerintahan

Dalam struktur pemerintahan di Desa Baruga Riattang Kecamatan Bulukumpa Kabupaten Bulukumba, di pimpin oleh Kepala Desa. Dalam menjalankan pemerintahan, Kepala Desa dibantu oleh Kepala Urusan (Kaur) sedangkan sekertaris Desa saat ini tidak ada yang menjabati. Adapun sususan pemerintahan Desa Baruga Riattang tahun 2016 sebagai berikut

Tabel I

Struktur Organisasi Pemerintahan pada tahun 2016

\begin{tabular}{|l|l|l|}
\hline No & Jabatan & Nama \\
\hline 1 & Kepala Desa & A.Hamzah S.pd, M.si \\
\hline 2 & Sekertaris Desa & - \\
\hline 3 & Ka. Ur. Pemerintahan & Asri, S.E \\
\hline 4 & Ka. Ur. Kesos & Sukmawati \\
\hline 5 & Ka. Ur. Umum & Rismawati \\
\hline
\end{tabular}

(Sumber data monografi Desa Baruga Riattang, 2014) 


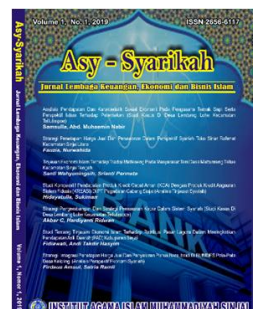

Asy-Syarikah

Jurnal Lembaga Keuangan, Ekonomi dan Bisnis Islam

Volume 2, No. 2, 2020

ISSN (print) : 2656-6117

ISSN (online) : 2715-0356

Homepage : http://journal.iaimsinjai.ac.id/index.php/asy-syarikah

\subsubsection{Praktek Jual Beli Mappaje di Desa Baruga Riattang}

\section{Pengertian Jual-Beli Mappaje}

Masyarakat di Desa Baruga Riattang Kecamatan Bulukumpa Kabupaten Bulukumba disamping sebagai petani, mereka juga sebagai pedagang dan pegawai. Dalam hal pertanian itupun sendiri, maka tidak lepas dari kegiatan perdagangan, dimana mereka memperjualbelikan hasil pertaniannya. Namun, dalam mengelolah hasil pertanaian tersebut, terkadang mereka memilih sebuah alternatif dengan mejualnya dalam keadaan masih di pohon. Hai ini di karenakan mereka tidak ingin bersusah payah mengeluarkan tenaga lagi untuk memetiknya sendiri, apalagi jika ada kebutuhan yang mendesak. Hasil pertanian yang mereka perjualbelikan tersebut adalah milik mereka sendiri

Bentuk jual beli yang dilakukan oleh masyarakat Islam, khususnya di Desa Baruga Riattang, yaitu mereka menyebutnya dengan istilah mappaje', yaitu jual beli hasil tanaman seperti biji-bijian atau buah-buahan yang masih dipohon dalam bentuk penaksiran, dimana buahnya akan diambil atau dipanen oleh si pembeli sesuai dengan kesepakatan diantara kedua belah pihak, penjual dan pembeli. Orang yang menjual disebut pabbalu' mappaje' dan pembeli disebut pangngelli mappaje'.

Sebagai mahkluk sosial, semua manusia pasti membutuhkan orang lain dalam kehidupannya untuk dapat hidup bermasyarakat dan saling berinteraksi satu sama lain. Dengan demikian, terjadilah muamalah seperti adanya praktik jual beli yang disebut mappaje' yang dilakukan oleh masyarakat di Desa Baruga Riattang.

Akad mappaje' dilakukan dengan asumsi saling percaya diantara kedua belah pihak, tanpa ada cataatan seperi kwintansi sebagai bukti jual beli dintara mereka. Dalam praktik mappaje' yang ada di Desa Baruga Riattang, mula-mula si A (pabbalu' mappaje') menceritakan kepada salah satu tetangganya tentang keinginannya untuk menjual hasil tanamannya dengan cara mappaje'. Kemudian tersebar luas kemasyarakat lain hingga sampai kepada si B (pangngelli mappaje'). Maka si B (pangngelli mappaje') kemudian mendatangi rumah si A (pabbalu' mappaje') untuk mengungkapkan keinginannya membeli hasil tanaman si A (pabbalu' mappaje') dengan cara mappaje'. Setelah itu, mereka bersama-sama datang kekebun si A (pabbalu' mappaje') untuk melihat keadaan hasil tanaman yang akan dijual. Disinilah si B (pangngelli mappaje') mulai memperhatikan bagaimana keadaan hasil tanaman tersebut. Setelah diperhatikan dengan baik, maka kemudian si B (pangngelii mappaje') akan mentaksirkan kira- kira berapa banyak jumlah atau takaran dari hasil tanaman tersebut setelah dipanen. Dalam melakukan penaksiran, pembeli dinggap sudah mampu mentaksir banyaknya jumlah buah setiap pohon hanya dengan melihat dan memperhatikan buah yang ada di pohon tersebut, karena pembeli sudah terbiasa dan berpengalaman dalam melakukan penaksiran seperti itu. Biasanya, pihak pembeli mentaksir dengan melihat seberapa besar pohonnya dan seberapa banyak buah yang akan dihasilkan nantinya. Setelah itu, si A (pabbalu' mappaje') memberikan harga penjualan kepada si B (pangngelli mappaje') terhadap barang yang dijadikan objek mappaje' tersebut. Kemudian dilakukanlah tawar-menawar mengenai harga dari hasil tanaman tersebut hingga terjadi kesepakatan.

Dalam penentuan harga, pembeli mentaksir atau mengira-ngira seleruh buah yang ada di pohon. Biasanya, dalam satu pohon itu buahnya dikira-kira atau dihitung berapa banyak yang akan dihasilkan setelah panen. Setelah dihitung, kemudian pembeli menentukan harganya dan saling tawar-menawarlah antara penjual dan pembeli, hingga sampai ditetapkan harga dengan saling rela atau ridha. Mengenai penetapan harga dalam jual beli tersebut, juga tetap berpatokan pada harga pasar. 


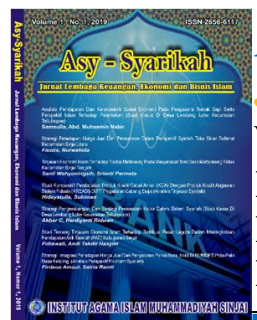

Asy-Syarikah

Jurnal Lembaga Keuangan, Ekonomi dan Bisnis Islam

Volume 2, No. 2, 2020

ISSN (print) : 2656-6117

ISSN (online) : 2715-0356

Homepage : http://journal.iaimsinjai.ac.id/index.php/asy-syarikah

Setelah harga ditetapkan dan disepakati, maka dilakukanlah pembayaran. Pembayaran dilakukan penjual kepada pembeli, biasanya pada saat terjadi kesepakatan dengan alasan sangat membutuhkan uang tersebut akan keperluan mendesak. Sehingga pembeli dianggap sebagai penolong karena disaat mereka membutuhkan uang, pembeli mappaje' siap untuk membelinya. Selain itu, pembayaran juga bisa dilakukan dengan membayar sebagian uang terlebih dulu. Hal ini biasanya disebabkan karena tingginya jumlah uang yang harus dibayar, seperti dalam jual beli buah cengkeh yang harganya relatif tinggi, misalnya mencapai puluhan juta, maka si penjual pun memberikan waktu beberapa hari kepada si pembeli untuk melunasinya. Bahkan juga bisa setelah pemanenan selesai barulah dibayar lunas. Sedangkan dalam jual beli seperti buah langsat atau rambutan, pada umumnya dibayar lunas, karena jumlah uang yang harus dibayar biasanya hanya berkisar ratusan ribu. Masalah pembayaran uang tersebut, semua sesuai dengan kesepakatan yang dilakukan antara penjual dan pembeli tanpa ada unsur paksaan.

Adapun cara pemanenannya, yaitu biasanya dilakukan skaligus. Seperti dalam pemanenan buah langsat atau rambutan, yang biasanya jumlah pohonnya paling banyak 5 pohon. Dilakukan dengan cara bertahap atau tidak sekaligus panen, biasanya terjadi dalam pemanenan buah cengkeh, yang apabila jumlah pohonnya mencapai puluhan pohon. Sehingga pemanenan dilakukan secara bertahap sampai buah setiap pohon itu habis dipanen. Selain itu, waktu pemanenannya juga bisa sesuai dengan keinginan si pembeli, karena buah yang ada di pohon tersebut sudah menjadi hak miliknya setelah dilangsungkannya akad dan penjual sama sekali tidak memberikan syarat pemetikan terhadap buah yang telah di beli oleh si pembeli tersebut.

Penyusun memperoleh informasi/data mengenai alasan masyarakat di Desa Baruga Riattang melakukan praktik mappaje', baik penjual maupun pembeli mappaje'.

Alasan bagi para penjual melakukan jual beli mappaje', yaitu:

1. Penjual melakukan praktik mappaje', karena mereka memperkirakan apabila melakukan pemanenan sendiri akan membutuhkan biaya lagi, seperti membayar upah pemgambilan hasil tanaman yang dipanen dan biaya konsumsinya.

2. Penjual melakukan praktik mappaje', karena mereka memiliki perkebunan yang luas yang harus diolah dan tidak mampu mengolah semua hasil pertaniannya. Sehingga mereka memilih menjual hasil tanamannya dengan cara mappaje'.

3. Penjual melakukan praktik mappaje', karena mereka ingin cepat mendapatkan uang guna untuk memenuhi kebutuhan mendesak, seperti keperluan anak-anak sekolah atau keperluan lainnya, yang apabila diambil atau dipanen sendiri akan memakan waktu yang cukup lama.

Alasan melakukan jual beli mappaje' bagi pihak pembeli, yaitu untuk memperoleh keutungan dari hasil pembelian itu, guna memenuhi kebutuhan keluarga. Selain itu, juga sebagai bentuk tolong-menolong di antara mereka. Dimana, pembeli bisa membantu orang lain yang memiliki kebutuhan mendesak dengan cara mappaje' tersebut.

Selain itu, mereka melakukan praktik mappaje' karena sudah terbiasa sejak zaman dahulu, yang dianggap sebagai bentuk tolong-menolong diantara mereka. sehingga mereka beranggapan bahwa hal tersebut sudah menjadi adat kebiasaan. Maka karena sudah terbiasa, sehingga sudah menjadi ketetapan umum bila menjul hasil tanaman dengan cara mappaje'.

\section{Pendapat Tokoh Masyarakat mengenai Praktik Jual Beli Mapppaje'}

Menurut salah seorang tokoh masyarakat di Desa Baruga riattang, Bapak Ali berpendapat bahwa, praktik mappaje' yang dilakukan oleh masyarakat di Desa Baruga Riattang tersebut boleh dilakukan. Salah satu alasan yang paling utama dikatakan bahwa, praktik mappaje' tersebut sudah merupakan kebiasaan masyarakat yang secara turun 


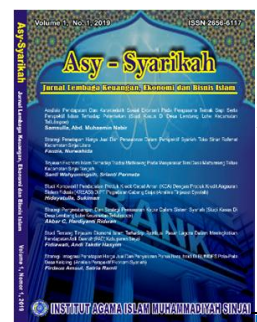

Asy-Syarikah

Jurnal Lembaga Keuangan, Ekonomi dan Bisnis Islam

Volume 2, No. 2, 2020

ISSN (print) : 2656-6117

ISSN (online) : 2715-0356

Homepage : http://journal.iaimsinjai.ac.id/index.php/asy-syarikah

temurun dilakukan. Dalam pelaksanaan mappaje', tidak menghadirkan saksi dan dilakukan secara suka rela dan tanpa adanya paksaan dari pihak lain. Dalam praktik mappaje', sebelum terjadi kesepakatan terlebih dahulu pembeli melihat langsung keadaan buah hasil tanaman yang akan diperjualbelikan. Disinilah, pembeli mulai memperhatikan buah yang ada di pohon mengenai kelayakan buah jika dipanen nanti dan bisa di prediksi jelas baiknya. Kemudian pembeli melakukan penaksiran terhadap buah tanaman tersebut, tentang banyaknya hasil panen yang akan didapat nantinya. Setelah itu, mereka melakukan tawar-menawar harga antara kedua belah pihak hingga terjadi kesepakatan diantara keduanya. Selain itu, Bapak Ali juga menambahkan bahwa praktik mappaje' ini juga merupakan alternatif yang mempermudah masyarakat dalam jual beli. Dimana seorang penjual tidak perlu bersusah payah lagi untuk memanen hasil tanamannya untuk dijual dan mendapatkan uang. Akan tetapi, penjual tersebut bisa menadapatkan uang secara langsung dari pembeli dengan cara mappaje' ini.

\subsubsection{Praktek Jual-Beli Mappaje’ Perspektif Islam}

Jual beli adalah menukar barang dengan barang, atau barang dengan uang dengan jalan melepaskan hak milik dari yang satu kepada yang lain atas dasar saling merelakan. Jual beli merupakan akad dalam bermuamalah yang dilakukan oleh dua pihak, yaitu penjual dan pembeli. Dalam hukum Islam, kegiatan jual beli sudah ada sejak dahulu zaman Rasulullah saw. dan merupakan kegiatan yang diperbolehkan. Bahkan dianjurkan karena merupakan sarana tolong-meolong antara sesama manusia dalam memenuhi kebutuhan hidupnya.

Jual beli adalah menukar barang dengan barang, atau barang dengan uang dengan jalan melepaskan hak milik dari yang satu kepada yang lain atas dasar saling merelakan. Jual beli merupakan akad dalam bermuamalah yang dilakukan oleh dua pihak, yaitu penjual dan pembeli. Dalam hukum Islam, kegiatan jual beli sudah ada sejak dahulu zaman Rasulullah saw. dan merupakan kegiatan yang diperbolehkan. Bahkan dianjurkan karena merupakan sarana tolong-meolong antara sesama manus Adapun bentuk jual beli yang dilakukan oleh masyarakat di Desa Baruga Riattang Kecamatan Bulukumpa Kaupaten Bulukumba, yaitu mereka menyebutnya dengan istilah mappaje', dimana yang menjadi objek jual beli yaitu buah yang masih di pohon dan dilakukan dalam betuk penaksiran. Jika dilahat dari segi rukunnya, ada akad yang diakukan antara penjual dan pembeli, yaitu berupa penyerahan barang (ijab) dari penjual dan penerimaan ( $q a b u l$ ) dari pembeli. Jadi, jelas ada orang sebagai pelaku akad serta ada barang yang menjadi objek jual beli. Sehingga rukun dalam jual beli tersebut telah terpenuhi. Mengenai syaratnya, yaitu orang yang melaukan akad mappaje' ini sudah tamyiz atau dewasa dan sudah mampu mengendalikan hartanya. Karena dalam Islam, dilarang melakukan jual beli bagi orang yang belum tamyiz anak kecil maupun orang gila. Adapun akad yang dilakukan, yaitu bersesuaian antara ijab dan qabul yang diucapkan antara penjual dan pembeli. Sedangkan barang yang dijadikan objek jual beli mappaje' tersebut, ada dan dapat dilihat oleh mata meskipun masih di pohon. Jadi, barang yang dijadikan objek jual beli mappaje' tersebut, bukan barang yang haram atau yang diharamkan, seperti yang dijelaskan dalam hadis di atas. Selain itu, meskipun masih di pohon, akan tetapi barang yang diperjualbelikan tersebut sudah dapat diketahui bentuk dan wujudnya. Karena barang itu ada dan dapat dilihat oleh mata. Sedangkan barang yang tidak dapat dilihat baik bentuk maupun wujudnya, bisa menimbulkan terjadinya penipuan sehingga dilarang. Jadi, jual beli benda yang tidak ada serta tidak dapat dilihat oleh mata ialah juala beli yang dilarang dalam agama Islam, karena barangnya tidak tentu atau masih gelap. Selanjutnya, barang yang diperjualbelikan dalam praktik mappaje' tersebut merupakan milik sipenjual (pabbalu' mappaje') itu sendiri dan bermanfaat bagi kehidupan manusia serta dapat 


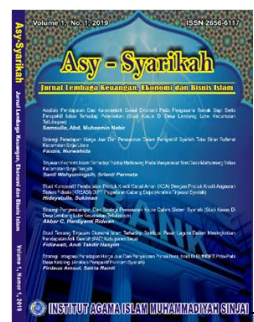

Asy-Syarikah

Jurnal Lembaga Keuangan, Ekonomi dan Bisnis Islam

Volume 2, No. 2, 2020

ISSN (print) : 2656-6117

ISSN (online) : 2715-0356

Homepage : http://journal.iaimsinjai.ac.id/index.php/asy-syarikah

diserahkan. Meskipun masih berada di pohon, namun barang yang diperjualbeikan itu sudah jelas kelayakannya untuk dipetik, bahkan bisa dipetik seketika akad itu terjadi sesuai dengan keinginan pembeli (pangngelli mappaje') terhadap barang yang telah dibelinya tanpa ada syarat pemetikan dari penjual.

Dalam transaksi jual beli, objek jual beli (ma'kud 'alaih) merupakan hal penting dan sangat berpengaruh terhadap keabsahan jual beli tersebut. Mengenai objek jual beli, yaitu barang yang diperjualbelikan harus suci, jelas bentuk dan wujudnya, dapat diserahterimakan, bermanfaat, milik sendiri dan tidak dibatasi waktunya. Karena dalam hukum Islam, dilarang memperjualbelikan barang yang dikategorikan barang yang najis atau diharamkan oleh syara', tidak dapat dimanfaatkan atau tidak bermanfaat bagi manusia.

buah-buahan yang masih di tangkai atau belum dipetik, dilarang diperjualbelikan sebelum matang dan bebas hama. Sedangkan dalam praktik mappaje' yang dilakukan oleh masyarakat Islam di desa Baruga Riattang, dalam jual beli buah yang masih di pohon, itu sudah jelas kelayakannya untuk dipetik atau buah yang ada di pohon tersebut sudah tampak tua dan matang dan bahkan adapula yang dipetik seketika setelah akad berlangsung.

Maka jika dilihat dari proses pelaksanann mappaje' tersebut di atas, praktik mappaje' yang dilakukan oleh masyarakat Islam di Desa Baruga Riattang itu sudah sesuai dengan ketentuan jual beli dalam hukum Islam, karena semua rukun maupun syaratnya telah terpenuhi. Sehinnga praktik mappaje' tersebut tidak termasuk dalam jual beli yang dilarang atau diharamkan dalam Islam.

\section{Kesimpulan}

1. Praktik mappaje' pada masyarakat Islam di Desa Baruga Riattang Kecamatan Bulukumpa Kabupaten Bulukumba, yaitu mula-mula si A (pabbalu' mappaje') menceritakan kepada salah satu tetangganya tentang keinginannya untuk menjual hasil tanamannya dengan cara mappaje'. Kemudian tersebar luas kemasyarakat lain hingga sampai kepada si B (pangngelli mappaje'). Maka si B (pangngelli mappaje') kemudian mendatangi rumah si A (pabbalu' mappaje') untuk mengungkapkan keinginannya membeli hasil tanaman si A (pabbalu' mappaje') dengan cara mappaje'. Penjual dan pembeli melakukan akad mappaje' atas dasar kerelaan dan kesepakatan bersama setelah pembeli melihat dan memperhatikan langsung keadaan barang yang ada di pohon. Kemudian ditaksirkan, lalu terjadi tawar-menawar mengenai harga hingga sampai pada harga yang disepakati dan terjadi kesepakatan jual beli.

2. Dalam perspektif hukum Islam, praktik mappaje' boleh dilakukan karena baik rukun maupun syarat dalam jual beli tersebut telah terpenuhi dan saat dilakukan proses jual beli, buah yang ada di pohon tersebut sudah jelas kelayakannya untuk dipetik atau sudah tampak tua dan bahkan adapula yang dipetik seketika setelah akad berlangsung.

\section{Ucapan Terima Kasih}

Artikel ini merupakan tulisan berbentuk jurnal yang disusun oleh penulis pertama dan kedua dengan bantuan beberapa pihak, untuk itu penulis mengucapkan banyak terima kasih kepada seluruh pihak yang telah membantu sehigga tulisan ini bisa diterbitkan.

Daftar Pustaka

Ali Bassam, Abdullah bin Abdurrahman. Syarah Hadis Pilihan Bukhari Muslim. Jeddah: Maktabah As-Sawady Lit-Tauzi', 1992. 


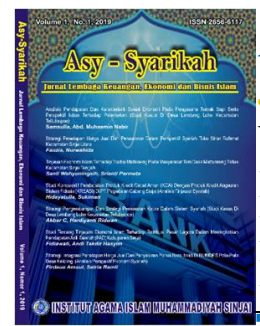

Asy-Syarikah

Jurnal Lembaga Keuangan, Ekonomi dan Bisnis Islam

Volume 2, No. 2, 2020

ISSN (print) : 2656-6117

ISSN (online) : 2715-0356

Homepage : http://journal.iaimsinjai.ac.id/index.php/asy-syarikah

Anwar, Syamsul. Hukum Perjanjian Syariah : Studi tentang Teori Akad dalam Fikih Muamalat. Jakarta: PT RajaGrafindo Persada, 2007.

Arikunto, Suharsini. Prosedur Penelitan: Suatu Pendekatan Praktek. Jakarta: PT. Ranika Cipta, 1998.

Ash-Shiddieqy, Teungku Muhammad Hasbi. Koleksi Hadits-hadits Hukum. Semarang: Pustaka Rizki Putra. 2011.

Al-Asqalani, Ibnu Hajar Al-Hafizh. Terjemahan Lengkap Bulughul Maram. Cet. V; Jakarta: Akbar madia, 2010.

Azwar, Saifuddin, Metode Penelitian. Yogyakarta: Pustaka Pelajar, 2003.

Cahyani, Andi Intan. Fiqh Muamalah. Makassar: Alauddin University Press, 2013.

Darussalam, Andi. Hadis Ibadah dan Muamalah. Makassar: Alauddin University Press, 2014.

Fathoni, Abdurrahman. Metodologi Penelitian dan Teknik Penyusunan Skripsi. Jakarta: PT. Asdi Mahasatya, 2006.

Ibrahim, Metodelogi penelitian Kualitatif . Bandung: Alfabeta, 2015.

Irfan. Hukum Transaksi. Makassar: Alauddin University Press, 2014.

Kementerian Agama RI. Al-Qur'an dan Terjemahnya. Jakarta: PT. Sinergi Pustaka Indonesia, 2012.

Khaeriyah, Hasan Hamzah. Fiqh Iqtishad Ekonomi Islam. Makassar: Alauddin Press, 2013.

Mas'adi, A. Ghufran. Fiqh Muamalah Kontekstual. Cet. I; Jakarta: PT RajaGrafindo Persada, 2002.

Minhajuddin. Hikmah dan Filsafat Fikih Muamalah Dalam Islam. Cet. I; Makassar: Alauddin University Press, 2011.

Muhajir, Neong, Metedologi Penelitian Kualitatif. Yogyakarta: Rake Selatan, 1998.

Muslim, Al-Imam. Terjemah Hadis Shahih Muslim. Jakarta: Klang Book Centre, 2007.

Qaman, Nurul, Perbandingan Sistem Hukum dan Peradilan. Makassar: IKPI, 2010.

Rasjid, H. Sulaiman. Fiqh Islam. Bandung: Sinar Baru Algensindo, 2012.

Republik Indonesia. Kitab Undang-Undang Hukum Perdata. Jakarta: PT. Rineka Cipta, 1992.

Rina was, Pengertian Metodologi dan Metodologi Penelitian (Powered: by Blogger, 2011) http://ribhy.ini-aja.com/just/bahasa-indonesia-just/metodologi-penelitian/ (30 April 2013).

Subagyo, P. Joko. Metode penelitian dalam Teori dan Praktek. Jakarta: Rineka Cipta, 1997.

Suhaedi, Hendi. Fiqh muamalah. Jakarta: PT RajaGrafindom Persada, 2002.

Suryabrata, Suryadi. Metodologi Penelitian. Jakarta: Raja Grafindo Persada, 1998.

Syafei, Rahmad. Fiqih Muamalah. Bandung: Pustaka Setia, 2000. 